\title{
The Sterile or Life-Denying Society: \\ Women and Evil in Contemporary American Novels ${ }^{*}$
}

\begin{abstract}
Society is a joint-stock company, in which the members agree, for the better securing of his bread to each share-holder, to surrender the liberty and culture of the eater. The virtue in most request is conformity. Self-reliance is its aversion... Whoso would be a man, must be a nonconformist.
\end{abstract}

by Ralph Waldo Emerson, "Self-Reliance".

Charles MASINTON Universidad Nacional Autónoma de México

At first glance, it might appear that contemporary American novelists have largely turned away from the age-old problem of evil to concern themselves with purely esthetic matters or with issues relating to a technological, urban, post-Christian society, an "enlightened" society in which what used to be understood as evil can be accounted for in psychological, sociological, political, or scientific terms. But this is not the case. While some of our serious, critically celebrated novelists since the end of World War II - John Barth, Robert Coover, William H. Gass, and Vladimir Nabokov come to mind- have dedicated themselves principally to the formal and technical aspects of their craft, an imposing number of contemporary novelists recognize the reality of evil in human affairs and represent it in a wide variety of ways. In contrast to those writers named above, for whom novels are primarily objects of beauty and delight and not vehicles for communicating social or philosophical insights, most important American novelists still address the pressing issues of day-to-day existence, including the problem of evil.

* Este artículo apareció originalmente en Nezu Mexico Humanities Reriew, vol. 9, núm. 1 (Spring, 1986), pp. 40-59. Agradecemos al autor su autorización para reproducirlo. 
Evil as identifiable subject matter, however, is not immediately apparent to many readers of contemporary American novels because of the absence of a traditional theological framework that would clearly define good and evil. Notable exceptions do, of course, occur: no writer of our time has a surer sense of evil than Flannery O'Connor, whose fiction sharply reflects her Catholic heritage and is usually overtly religious in subject matter as well. Yet it remains the case that more often than not our best-known and critically mostrespected writers are secular in their outlook and represent the many evils in human experience from a humanistic and worldly, not a religious or theological, perspective.

Even John Updike, despite his Christian beliefs and the strong presence of religious themes in many of his works, stresses the secular and temporal aspects of life in his fiction to give it the unique qualities that it has. Writing squarely in the middle of the realistic tradition, Updike lavishes attention on the minutiae of everyday, middle-class experience and makes his readers feel as if they are entering his fictional world as participants in a living drama. Theological concerns clearly help shape the narrative in Rabbit, Run, probably his best-known novel, but the enduring strength of that work lies in its realistic, sympathetic characterization and its faithful re-creation of a historical moment in the U.S. - the late 1950's. And in such works as the other Rabbit novels, or the two books that deal with the writer Bech, for example, Updike's religious sensibility disappears beneath his robust concern for documenting the here-and-now and treating problems of the contemporary artist. In The Witches of Eastwick, his most recent novel, the three "witches" are divorcees who have developed demonic powers and whose lives are disrupted by the abrupt appearance in their midst of a stranger who eventually proves to be the Devil. But this novel is a witty commentary on contemporary feminist attitudes and the "liberated" condition of today's divorced woman, not an investigation into theological issues like the influence of the Devil or the ultimate origins of evil in present-day life. It is a comedy of manners in which the "witchcraft" of the women is but a clever conceit allowing Updike to dramatize more boldly how divorce in a small New England community has brought about changes in character in his three central figures.

What the absence of a traditional theological scheme in the works of a majority of our important novelists proves is not that the problem of evil has become anachronistic but that it is represented in 
terms more familiar, and perhaps more acceptable, to contemporary readers. The novel as a literary form has from the beginning tended toward a preoccupation with the daily concerns of the middle class and with the crises of average men and women. So it is no surprise that contemporary novelists -including those, like Updike and Walker Percy, to name another writer with religious leaningsdramatize the confrontation with evil in a more realistic and mundane manner than, say, Greek tragedy or the epic poem would. The evils typical of life in the 20th century (the threats to the individual posed by the social order, world war, urban violence, psychological abnormality, the collapse of moral absolutes), as experienced by unexceptional and often antiheroic characters, fill the pages of important contemporary American novels.

Demon-possessed or Satanic children, heroic battles with the Devil or one of his emissaries, houses haunted by loathsome spirits bent on terrorizing frail humans, automobiles with evil souls, attacks by gigantic and malevolent sharks or dogs that suggest the monsters of ancient inyths or legends and embody the anti-human forces of the universe - these sensational kinds of evil are the stuff of popular fiction, not the serious fiction of our times. Occult powers, supernatural evils, and superstitious lore abound in recent popular novels, many of which are silly offshoots of the Gothic tales and novels of the 18 th and 19 th centuries. These popular works can make no legitimate claim to reflect contemporary actualities - good, evil, or otherwise. Works like The Omen. Carvie. The Exorcist, The Amityville Horror, Chistine, Rosemany's Baby, Jaus, Cujo, and The Shiming are written to provide entertainment or thrills to relatively undiscriminating readers who constitute a mass market - and to make money for their authors, naturally.

The presence of the occult and the eruption of supernatural horrors found in these novels are almost entirely absent from the serious fiction of our time. It is true that in Flannery O'Connor's works the supernatural world violently intrudes into the lives of her grotesque characters, but she does not intend to shock her readers for the sake of shock. She is trying to suggest by unsettling means the reality of a world beyond our immediate ken, the ineffable reality of Christian mystery. And when she does make the Devil a character, in The Violent Bear It Away, she avoids the merely melodramatic by first dramatizing this figure as the inner voice of the protagonist, a headstrong boy who resists his calling as a prophet. The Devil later 
materializes as a sleazy character who rapes the boy, but long before that time the Devil has been accepted by the reader as a credible element of the boy's psychological make-up as well as the Father of Lies. Thus the division between evil as represented in popular novels and evil as depicted in intellectually serious novels of the present age is clear. Evils of a supernatural kind or with an occult origin almost always appear in novels written for mass encertainment. The evils treated in novels that do not adhere to a commercial formula are subtler, more true-to-life, and ultimately more disturbing because they usually grow out of human nature and human institutions.

Several categories of evil might be described to take into account the works of serious contemporary American novelists. An obvious one would be War and the Holocaust, under which we could list such novels as William Styron's Sophie's Choice, Kurt Vonnegut's Slaughterhouse-Fize, Norman Mailer's The Naked and the'Dead, and Jerzy Fosinski's The Painted Bird. Another obvious category would bring together novels concerned with Doomsday, like Vonnegut's Cat's Cradle, Terry Southern's Dr. Strangelove, Bernard Malamud's God's Grace, Russell Hoban's Riddley Walker, and Walker Percy's Love in the Ruins. A third category, Corrupt or Fallen Man, would group together novels that concentrate on the evil in human nature. Such novels as Robert Penn Warren's All the King's Men, O'Connor's The Violent Bear It Away, and Truman Capote's In Cold Blood (a "nonfiction novel") might head this list, though The Painted Bird and God's Grace would have to be mentioned here too because these novels also deal with ineradicable evil in human nature. A fourth category might be called The Infernal City and would include those representations of urban hell that we find in certain works of William Burroughs, for example, or in Hubert Selby Jr.'s Last Exit to Brooklyn. (If popular fiction were being considered, most detective novels, which usually pit the lonely hero againt the forces of evil in urban settings, could also be included here.) A final category, The Sterile or Life-denying Society, would link those novels that emphasize the evil effects of social arrangements and institutions, from which the protagonist must at all costs flee. Such works as Joseph Heller's Calch-22, Ken Kesey's One Flew Over the Cuckoo's Nest, Norman Mailer's An American Dream, John Updike's Rabbit, Run, and John Hawkes's Second Skin fit together under this rubric. Although each category contains novels of importance, this essay will limit itself to an examination of only the last group. The five novels listed in this group, each one very different from the others in style 
and technique, update an old American literary tradition which tends to see goodness or innocence in the individual and corruption or evil in society. In particular, this tradition emphasizes the social conditions that abridge the freedom or threaten the individuality of the protagonist. Since the central motif of this tradition - the hero in flight from a society gone bad- has been extensively used by American writers since the early 19th century, a consideration of contemporary novels in which the motif reappears will not only identify literary patterns that writers still turn to for inventing character and event, but will also remind us of persistent attitudes in the American mind.

\section{II}

In a large number of notable contemporary American novels we find the motif of the threatened or alienated protagonist -always a male - who withdraws from society to seek safety, freedom, happiness, or self-renewal in a simpler environment, usually a pastoral landscape or borderland which is often faintly reminiscent of the Western frontier. The tradition of the American literary hero's unsatisfactory engagement with society stretches back at least as far as James Fenimore Cooper's Leather-Stocking Tales, a series of five novels published from 1823 to 1841 in which Natty Bumppo (LeatherStocking) prefers life in the forests to the destructive and constricting ways of the Eastern settlements. This hardy tradition manifests itself in Thoreau's great autobiographical work, Walden, or Life in the Woods (1854) and continues through Hucklebery Finn (1884), in which Huck, a pure-hearted boy, preserves his safety and freedom from the corrupt folks on the shore by living on the Mississippi River with Jim. At the end of the novel Huck is preparing to "light out for the Territory" in the West to await more adventures with his friend Tom Sawyer.

1 Leo MARX demonstrates the immense importance of the motif of escaping from society to an idealized landscape in 19th-century American literature and culture in The Machine in the Garden: Technology and the Pastoral Ideal. New York, Oxford Univ. Press, 1967. He mentions only briefly its appearance in such 20th-century writers as Hemingway, Fitzgerald, and Frost. His principal concern is to investigate the conflict in the American mind between technological progress and the ideal of the pastoral retreat. 
The motif of the hero's withdrawal from the strictures and dangers of society to find solace in nature crops up again in the 20th century most forcefully before the present era in some of Ernest Hemingway's best fiction. Jake Barnes in The Sun Also Rises (1926) finds peace of mind only when he goes fishing with his friend Bill in the Spanish mountains on the Burguete River, away from the sexual complications centering about the triangle of Lady Brett Ashley, Robert Cohn, and Brett's fiancé Mike Campbell. Nick Adams, the protagonist of In Our Time (1925), has a history of being wounded psychologically and physically as he grows up and enters the world. At the end of the volume, in "Big Two-Hearted River", Nick, a shell-shocked veteran of World War I, retreats to the Michigan woods alone to fish and try to forget about the nightmare of the past in the healing river and woods. And in A Farewell to Arms (1929) Fred Henry makes "a separate peace" by deserting the Italian army and escaping with Catherine to an idyllic mountain setting in Switzerland.

In the contemporary era the motif of the protagonist's retreat from the disabling influences of society to a natural landscape, or at any rate to some simple or idealized setting, continues not only in works by writers who clearly have been influenced by Hemingway - works like James Dickey's Deliverance (1970) and Thomas McGuane's Ninety-Two in the Shade (1973) - but also in novels of less "macho" writers like Joseph Heller (Catch-22 [1961]), John Updike (Rabbit, Run [1960]), and John Hawkes (Second Skin [1964]). The motif, however, tends strongly to stress masculine values and roles and to downplay or denigrate women's roles. Norman Mailer's An American Dream (1965) and Ken Kesey's One Flew Over the Cuckoo's Nest (1962) serve as striking illustrations of this point. The protagonists of these works, one a war hero and the other a chronic brawler, are put-upon men whose deadliest foes turn out to be powerful women, figures who embody the chief elements of evil in each novel. Mailer's Stephen Rojack must actually engage in mortal combat with his wife Deborah before he can begin his journey toward health and freedom, just as R. P. Mc Murphy in Kesey's novel is forced to join in a lethal struggle against Big Nurse in the madhouse ward in an attempt to secure freedom for himself and his friends.

The novels by Kesey and Mailer remind us that the great antagonist of the central figures in this tradition is frequently Woman -if not a specific woman, then what she represents: a loss of manhood, dull social conventions, or the vexing complication related to marriage 
and family life. Both Big Nurse and Deborah very specifically threaten the manhood of McMurphy and Rojack. Rojack's complete loss of vitality and McMurphy's lobotomy in fact amount to symbolic castrations. Big Nurse in the end triumphs over McMurphy, but Rojack fights free of Deborah, who has tried to knee him in the groin and then grabbed for his genitals with both hands, by breaking her neck. Huck's situation is less melodramatic but no less debilitating in the long run, for he knows instinctively that he needs to stay away from Miss Watson and her kindly sister, the Widow Douglas, the woman who has taken him in as a son and wants to send him to school, teach him manners, and in general "sivilize" him. The keynote is struck in Huckleberry Finn and continues to reverberate in fiction of the present day: civilization and Woman are synonymous, and a man stands to lose something precious if he gives up his independence or life with his male companions for a stifling existence associated with schools, churches, wives, children, and jobs. ${ }^{2}$

This vision of freedom or well-being is at bottom a young man's dream, an adolescent fantasy, because it seeks to preserve the purity of childhood or the simple, unencumbered life of a bachelor. Thus it is hardly surprising that the writers whose works reflect this vision of life have usually insisted on the innocence of their male protagonists in the clash of the individual with the social order. R. W. B. Lewis, in The American Adam, demonstrates how important the concept of innocence was for many great American writers of the 19th century and how often those writers, who included not only Cooper and Twain but also Nathaniel Hawthorne and Herman Merville, framed narratives in which a figure of exemplary innocence or virtue has an incompatible and occasionally tragic relationship with his society. 3 We are a century away from the publication of Huckleberry Finn, but

2 Diana TrILliNG, in "The Image of Women in Contemporary American Literature", in The Woman in America, ed. Robert Jay LIFTON. Boston, Houghton Mifflin, 1965, p.63, makes the point that in much contemporary American fiction the protagonist identifies "the destructive female force with the destructive social force: woman is society in all its dark, unspecifiable lust and horror". See also the excellent book by Ann Douclas called The Feminization of American Culture, New York, Alfred A. Knopf, 1977. Douglas demonstrates in great detail how culture in its negative aspects became associated with women in the Victorian era in America. Her larger object is to show how the feminization of America during this period has led to our modern mass culture.

3 R.W.B. LEWIS, The American Adam: Innocence, Tragedy, and Tradition in the Nineteenth Century, Chicago, University of Chicago Press, 1955. 
the Adamic figure lives on in the literature influenced by the youthful dream of escape.

In the 20th century the literary protagonists in this tradition are less childlike and pure, more compromised and weakened by the social environment, but the writers who create them still endow them with a special quality of innocence or blamelessness. Yossarian in Catch-22, for example, sleeps with every beautiful woman he can, evades his duties, and maintains a cynical attitude about everything connected with Army Air Force life on the fictional island of Pianosa. He is a chronic complainer who pities his simple friends who actually want to fight and die for their country. And in the end he escapes from Pianosa alone, headed -improbably, since Pianosa is close to Italytoward Sweden, a neutral country that will provide safety for an AWOL flier and is reportedly full of gorgeous blonde women. Yossarian lacks every heroic virtue, yet Heller justifies his running away because the society represented by the microcosmic Pianosa is hopelessly corrupt and dangerous to the individual.

Pianosa represents Heller's satiric vision of postwar America: an absurd, anti-human world where Big Business, symbolized in Milo Minderbinder's M \& $M$ Enterprises, blithely kills and destroys in the name of capitalism. All humane values collapse in a place where Milo can make a contract with the Germans to bomb his own men for a profit - a place, in addition, where Yossarian's commanding officer can unconscionably raise the number of missions his fliers have to go on just to further his own career. In this hilarious novel of Black Humor Heller makes the point that Yossarian's only moral choice is to withdraw from the social order that will kill him sooner or later if he stays in it. He will not survive indefinitely if he has to fly more and more missions, and there is no possibility that he and his comrades will ever get the leave that they have long ago earned. Life, he learns after watching his buddy Snowden die, is infinitely precious, and yet no one in power on Pianosa has any respect for human life.

The life-threatening world of Yossarian is not dominated or typified by women, who in general are a source of wonder and delight to him, though ironically he is hospitalized when an Italian whore knifes him near the end of the novel. When she comes after him a second time, he literally sprints from her to save himself -and he keeps on running for Sweden. Rabbit Angstrom, by contrast, Updike's best-known fictional figure, is in flight from the beginning. Whereas an idealized Sweden (a dimly envisioned Eden, really) 
represents a long life and unintermupted love for Yossarian, the warm American South, with its "orange groves and smoking rivers and barefoot women" 4 beckons Rabbit away from his pregnant and alcoholic wife Janice and his dead-end job as a salesman of kitchen gadgets. For Rabbit, women are paradoxically associated with all of the social responsibilities he runs from and the lost sense of perfection that he is running to regain. In the opening pages of the novel, he begins the journey south in his car, but returns home to Mt. Judge when he loses his way. (This predicament early in the narrative could serve metaphorically as a comment on Rabbit's life throughout the novel). Instead of going home to Janice and his young son Nelson, however, Rabbit at once takes up with a sometime prostitute, Ruth, with whom he hopes to recapture some of the carefree joy and freedom he knew as a high-school basketball star, in a time that now seems a kind of Golden Age to him.

Rabbit's life in the present fills him with dread, with angst, as his surname hints to us. And so he frantically runs from the chicf source of his dread, the soul-numbing dreariness of his marriage with Janice, in hopes of finding with Ruth the lost glories of youth. What makes this novel more than just a story of a man who refuses to grow up is Updike's revelation that Rabbit's quest has a strong religious element in it, though Rabbit himself can only hint at his goal when he tells his friend Reverend Eccles: "Well I don't know all about this theology, but I'll tell you. I do feel, I guess, that somewhere behind all this' - he gestures outward at the scenery..._- 'there's something that wants me to find it'" (p. 120). On the basketball court Rabbit experienced a form of grace. Running up and down the court, scoring baskets effortlessly, knowing no limits to what he could do, he sensed that he had achieved a state of perfect wholeness, something that has disappeared entirely from his adult years.

His present life, depressing in its lack of vitality and barren in its prospects, threatens to crush his spirit. Ironically, even Eccles fails to recognize what Rabbit not only wants but also needs in order to feel fully alive. No one, in fact, except Rabbit, for all of his inadvertent cruelty and his profound irresponsibility, is searching for grace. Updike, a long-time student of the Christian theologian Karl Barth

${ }^{1}$ John UPDIKE, Rabbil, Run. New Y'ork, Ballantine Books, 1983, p. 29. Originally published in 1960 by Alfred A. Knopf. All quotations are from the Ballantine edition. Subsequent references will be found in the text in parentheses. 
and the Christian existentialist philosopher Sören Kierkegaard, implies a far-reaching criticism of the church in contemporary American society, for it has left Rabbit spiritually stranded and has permitted the society of which he is a member to grow moribund. Updike shows that present-day Christianity (insofar as Eccles' shallow pietism can be said to mirror it) hardly has the means to help Rabbit in his quest. Another minister in the novel, the old Luteran Kruppenbach, clearly represents a more vigorous expression of Christianity for Updike, but Rabbit does not encounter this character. Rabbit's world, as a result, seems empty and frightening to him. And so he runs, following his instinct for the transcendent glory that he claimed as a young man.

The reason that Rabbit turns to Ruth so readily is that he senses he might find in sexual intimacy with her some measure of the grace that with visceral certainty he knows is his birthright. Rabbit associates the delights of sex with the glory of his athletic achievements because in high school he would make love to his girl friend following his basketball games. Sex with her was perfect because it was uncomplicated and a part of being a hero, a "winner". He does not understand that he is confusing sex with a religious impulse; his nostalgia for glory simply drives him to seek personal salvation through the sexual act. He is conscious, though, of wanting more than just the momentary pleasure of sex with Ruth. He wants a self-transcending union with her as well. As the narrative voice of the novel says, "it is not her crotch he wants, not the machine; but her, her" (p. 77). And as they lie together, "he cannot dare enough, now that she is so much his friend in this search" (p. 82).

But Rabbit never finds what he searches for. He goes back to Janice when she delivers their second child, but abandons her a second time when she refuses his sexual advances. In despair, Janice gets drunk and accidentally drowns the new baby, and at the very end Rabbit, panicked that life has closed in on him, runs once again. The moment he chooses to run comes, shockingly, as his infant daughter is being buried: intolerably burdened with sorrow, guilt, and the suspicion that others blame him for the baby's death, he dashes away from the other mourners with no thought other than that of gaining freedom. He pauses long enough in his flight only to visit Ruth and learn that he has made her pregnant. Now he has no place at all to go. Janice and Ruth both represent unacceptable alternatives to him. All he can do is pick up his feet and run, but, as the closing paragraphs 
of the novel suggest, the route to escape is an illusion. His attempt to leave behind the deadening entanglements of responsible adult society will always be frustrated. Updike shows that in the conflict between irrepressible instinct and legitimate social demands no satisfactory solution exists.

The fictional world of Rabbit, Run accurately reflects middle-class American customs and attitudes of the late 1950's. Updike supplies countless realistic details to create a believable picture of American life at the end of the Eisenhower era. But he is far less interested in exposing the flaws in our social structure than in dramatizing through Rabbit's trials a human dilemma that we can all understand and in varying degrees sympathize with. We do not ordinarily consider the social limitations and expectations faced by Rabbit - the familiar contours of American life - to be evil. In what they deprive him of, however, they appear considerably more dire: spiritual wholeness (if not life itself), liberty, and happiness, what traditionally might be called his unalienable rights as an American. Rabbit is but one of many postwar American protagonists who fear, usually with good reason, that the social system will co-opt them, obliterate their identity, or even destroy them. In City of Words: American Fiction 1950-1970, Tony Tanner mentions very frequently the horror with which protagonists in recent American fiction regard the power of social institutions and arrangements to absorb them and rob them of their individuality or freedom. ${ }^{5}$ American society tends to be represented in the fiction of the past thirty-five or forty years as threatening or nightmarish, violence-ridden, managed by power-mad businessmen or corrupt politicians, or, as in the case of Rabbit, Run, spiritually stagnant. No one in Updike's novel seems productive or psychologically fulfilled; no marriage is happy; the characters, with the exception of Kruppenbach, live in the spiritual vacuum of a thoroughly secular world in which economic security and social conformity have replaced the hope of religious salvation. Since Rabbit, Run is not an all-out attack against modernity but rather a balanced, thoroughly convincing, and richly detailed depiction of an American life in recent times, its criticisms carry great weight for any sensitive reader. The novel provides a memorable example of the

5 Tony TANnER, Cily of Words: American Fiction 1950-1970. New York, Harper \& Rowe, 1971. 
image of the sterile or life-denying society which appears so frequently in postwar fiction. 6

Mailer's An American Dream, with its lurid, melodramatic picture of contemporary American society, presents a considerably more radical and anguished vision or our national ills and deserves consideration because Mailer imagines these ills as truly diabolical, the work of hellish powers. The novel offers a disturbingly vivid and intense evocation of a nighttime urban world guided not by ethical norms but debased by the lust for economic power and the trappings of success. Mailer sees a profound sickness underlying the national preoccupation with fame and wealth, and he does not flinch to call that sickness evil. Indeed, he goes so far as to trace the evil to its infernal source - the Devil. An American Dream is hardly a religious novel; nor does Mailer adopt a theological point of view. But he follows the moral cancer that invades his protagonist Stephen Rojack all the way back to a bargain made with the Devil by Rojack's father-in-law Barney Kelly, who obtains control of a vast corporate empire as a result of making a pact with Satan.

The infernal pact is Mailer's metaphoric way of dramatizing how profoundly American life has been corrupted by the kind of power generated by such a business tycoon as Barney Kelly and passed on to those whose lives he touches. The corruption spreads to Rojack when he marries Kelly's daughter Deborah, who is conceived at the moment when Barney calls on the Devil to help him impregnate his wife as a means of solidifying their shaky marriage and thus helping Barney to obtain the influential connections he had sought from the beginning through Deborah's mother. In a sense, then, Deborah is the Devil's child, and she demonstrates her penchant for evil by entering an incestuous relationship with her father. Unlike Janice, who unwittingly functions as the female who traps Rabbit within a society gone dead, Deborah, whom Rojack calls a "great bitch", 7 actively embodies

6 The power of the image has been considerably amplified, and a new dimension has been added, since the publication in 1922 of T.S. ELIOT's The Waste Land, which represents 20th-century experience as spiritually arid and singles out the modern city as a place where love is dead. Perhaps the most influential poem in English in the 20th century, it very soon made itself felt in the work of other writers, among them Fitzgerald and Hemingway.

7 Norman MAILER, An American Dream. New York, Dell Publishing. 1965, p. 16. All quotations are from this edition. Subsequent references will be found in the text in parentheses. 
the evil elements in American society, which her father greatly influences through his far-flung business interests.

Only toward the end of the novel does Stephen discover the truth about Barney and Deborah. During the opening pages, when he is psychologically and physically ill and wishes for death, he knows only that some debilitating force has entered him. He does not realize that Deborah, succubus-like, has possessed his vital center. Murdering her, then, is a necessary and positive action before Stephen can begin to rid himself of her poisonous influence. After the grisly murder scene, which Mailer does not hesitate to make repellent, Rojack starts the long journey back to wholeness as a man, and at the end of the novel, now a virtual outcast from his familiar world, he sets out for the jungles of Guatemala and Yucatán, a savage frontier far from the living death of contemporary America.

The America that Rojack flees has not withheld its gifts from him. He has been honored as a war hero and has served in Congress. He has written a widely read book, teaches a subject he calls "existential psychology" in New York, and is a well-known TV celebrity. He can even claim John F. Kennedy as a friend. Yet the price of his success is the soul-sickness that all but consumes him. He has achieved fame and married an heiress, but his reward is the rot that he feels spreading within him. What finally saves him is his fortunate fall from the pinnacle of success to the level of a criminal and social outsider. The police cannot prove that he has killed Deborah, but the bad publicity surrounding her death damages his reputation: his TV show is canceled, and he is asked to take a leave of absence from the university. By the time he decides to leave for Central America, when all the tokens and privileges of success have been stripped away from him, he has returned almost to full health. Having extricated himself from a society treacherously bent on destroying him, he is free to embark on a new beginning.

The Rojack that remains after his public personae have been removed is a man reduced to his primitive core, a creature of animal-like instincts who stays alive and free because he has moved outside of society's rules and laws. He has returned to a state of original innocence by obeying his instinct for survival, by becoming what Mailer labels a "Hipster" or "wise primitive" in his essay titled "The White Negro" (1957). ${ }^{8}$ The primitively wise man is both psychopathic

8 The essay, originally published in Dissent in 1957, is reprinted in Marler's Advertisements for Myself. New York, G. P. Putnam's Sons, 1959. 
and paranoid; but Mailer asserts that these states of mind are to be valued because they prepare the individual to survive in a world characterized by evils ranging from concentration camps to "totalitarian" sameness and conformity. "The White Negro" can be taken as a primer for understanding An American Dream, for Rojack evolves into the Hip hero envisioned in that piece. If the forces of contemporary society threaten the individual's existence at every turn, Mailer believes, then any form of violence can be justified to save oneself. When Rojack strangles his wife, it is not rational purpose but raw instinct that propels him. He has been humiliated by her (she boasts to him of her lovers); their marriage has all but emasculated him; and thus the extreme violence triggered in him when she lunges for his genitals follows the command of self-preservation as much as the impulse of sheer rage. It is hardly surprising that the act of murder itself engenders in him a sense of well-being and promise. Just as her neck begins to snap, Rojack has a vision of a door opening to reveal "heaven... some quiver of jeweled cities shining in the flow of a tropical dusk" (p. 35). And when Deborah dies, "that Oriental splendor of landscape" flowers into a "new grace" (p. 36) in Rojack and a feeling of rebirth.

Mailer uses the stereotype of the castrating female, then, as the agent of absolute evil, against whom murder is entirely justified (though to be fair to Mailer, he makes Rojack later recognize the enormity of taking a life). So profound is Mailer's disgust with mid-1960's America that he creates a fictional world in which commonly held notions of right and wrong are turned on their head as a means of getting his fevered vision across to the reader. An American Dream, despite its many realistic properties, is not intended as a documentary or descriptive account of the external world so much as an expression of Mailer's own deepest fears, fantasies, and obsessions regarding the dangers to manhood and individuality posed by American life. In its hallucinatory elements it more closely resembles an Expressionistic drama or painting -Eugene O'Neill's The Hairy Ape or Edvard Munch's The Scream, for example - than it does a realistic novel like Rabbit, Run or an intensely lifelike domestic scene by Jan Vermeer. Mailer's novel combines realism and a visionary or dream-like quality to produce an extremely personal work, a cri de coeur, lamenting the mortal sickness of America.

For all of his extremism, however, Mailer has had plenty of company in judging American institutions and the people who 
operate the levers of social or political power to be dangerous to individual liberty and well-being. Ken Kesey's One Flew Over the Cuckoo's Nest represents America as a mental institution, referred to by the inmates as the Combine, which degrades and unmans the individuals (all male, by the way) in it. Big Nurse Ratched, a soulless Super Mom, is the evil matriarch who wants only obedience and passiveness from the men under her "care". Only R. P. McMurphy, the brawling, womanizing protagonist who is brought to Big Nurse's ward from a work farm after the court decides that he is psychopathic, dares to oppose her. And in the end he suffers a horrible defeat: pre-frontal lobotomy cancels his supercharged aggressive and libidinal impulses, the very qualities that have given him his superior vitality. (In the crazy-house world over which Big Nurse presides, McMurphy's "psychopathic" characteristics make him seem absolutely sane and healthy; the "sanity" which she stands for is an enfeebled, mouse-like existence.) Not long after the surgery, his friend Chief Broom, the American Indian who narrates the novel, smothers McMurphy to death so that he will not serve as a reminder of Big Nurse's wicked power to the other inmates. Chief Broom then smashes his way out of the hospital, having symbolically absorbed the manly spirit of the martyred and Christ-like McMurphy, and returns to the remote fishing village of his tribe, a sanctuary near the Columbia River far away from the machine of society that violently destroys the manhood of its members.

Unlike Mailer's novel, One Flew Over the Cuckoo's Nest has much humor in it. Its over-simplified, good-guys-versus-bad-guys plot; its grotesquely enlarged, one-dimensional villainess; and its heroically magnified hero, in fact, give the book a comic strip or Pop Art quality. But in its depiction of the individual's desperate situation in America, it is deadly serious and has much in common with the malefic world of An American Dream. In both novels the protagonist's maleness, his sexual and manly force, invites the destructive powers of an evil woman. Big Nurse, the absolute boss of the tyrannical society into which McMurphy is thrust, systematically works to eliminate any expression of male sexuality in her ward, as evidenced by her rule that everyone take tranquilizers once a day and by her insidious collaboration with young Billy Bibbit's mother to keep Billy (a virgin) in a state of infant helplessness.

Another common element is the singular kind of innocence embodied in the protagonist. Neither Rojack nor McMurphy is sexually 
innocent; both commit crimes (McMurphy is jailed for constant fighting). Yet each is, like Yossarian, victimized by a dangerous and corrupt society he has had no hand in creating. Despite large flaws in their characters, they are morally and ethically superior to the social forces they so strenuously resist. Like Rabbit, they display a certain naiveté when they eventually register shock or outrage at the threatening circumstances they have encountered in the social environment. Yet every one of these figures is rebellions and intransigent enough to preserve an uncorrupted core of the self which is both life-affirming and seeks freedom above all else. ${ }^{9}$ McMurphy, in fact, personifies the traits of freedom and independence associated with the Western frontier. For Chief Broom, he has the uninhibited swagger of a cowboy, and he reminds Broom of fresh air and the healthy outdoors. It is McMurphy's brand of untamed masculine independence that the Combine is organized to suppress. When the Chief heads for home, psychologically reborn by his contact with McMurphy, he returns to the woods and the river that nourish the kind of freedom represented by his dead friend.

It is significant that McMurphy and Rojack, along with Yossarian and Rabbit, feel free with women and have enjoyable sexual relationships with them only outside the bonds of marriage - that is, outside the limitations of social convention. Rabbit moves in with Ruth, who has occasionally sold herself to other men. Yossarian regularly beds down with the whores he meets on leave. Rojack fails at marriage with Deborah, but meets a nightclub singer named Cherry (a slang word meaning "virgin"), has a glorious orgasm his first night with her, and imagines that he might some day settle down with her and commit himself to a life of useful work. (She is soon killed, however, by a drug-crazed black boyfriend who becomes jealous of Rojack). McMurphy, though confined to a mental ward, manages to make contact with his girlfriend Candy, a young hooker living in the vicinity. In fact, he takes her on an unauthorized fishing trip with his chums from the ward and on a later occasion smuggles her and a friend into the ward for a late-night party. The central event at that party is

9 This notion of innocence derives largely from the idea of "radical innocence" advanced by Ihab HASSAN in Radical Innocence: The Contemporary American Novel. Princeton, Princeton University Press, 1961, a study of postwar novels through 1960. Hassan singles out the following qualities in postwar fictional protagonists and gives them the label "radical innocence": the figure is "in recoil" (i.e., outraged and alienated) from society; he is flawed, a victim, and often a rebel or criminal; he is life-affirming, impulsive, anarchic, and irreducibly resistant to anything which would limit him or deny his freedom. 
the arrangement he makes with Candy to help Billy Bibbit lose his virginity, and it is this episode which precipitates the crisis in the novel. The next day Big Nurse learns what has happened and threatens to tell Billy's mother about him. Too fearful to face up to his mother, Billy cuts his throat and dies, an action which McMurphy responds to by attacking Big Nurse, ripping open the front of her uniform to expose her breasts, and trying to strangle her. Not long afterward the lobotomy is performed.

For these fictional males, the less-binding relationships they form with their girlsfriends seem more natural because they are less constricting. The relationships pose no threats to their liberty and sense of self. This observation applies even to Rojack, who envisions a happy marriage with Cherry, because Cherry, like Catherine Barkley in Hemingway's $A$ Farewell to Arms, represents a male fantasy of the perfect mate, a wish-fulfillment. Cherry is a healthy, all-American girl from the South for whom Rojack feels an immediate, almost magical attraction, which she also feels for him. She lets Rojack know what true love is really all about when she gives him the best orgasm of his life. Just as her name suggests the "first time", Rojack discovers during his first love-making with her the most intense and tender ecstasy of his life. Thus for Rojack the unnatural and destructive relationship exists with his wife (as is the case with Rabbit), while the easy, natural, and therefore good relationship quickly develops with Cherry. The institution of marriage connects Rojack and Rabbit with the social evils they must flee to preserve their integrity. Yossarian and McMurphy do not marry, but they feel perfectly happy with the casual yet sweet intimacies offered by whores.

This simple-minded division of female characters into whores and a "virgin" (who are associated with freedom and naturalness) and wives (who are linked with oppression and an unnatural way of life) is given a curious twist in Hawkes's Second Skin. Hawkes has received much critical attention for the postmodern qualities, especially the selfreflexiveness, of his fiction; for his ornate, densely textured prose style; and for his self-conscious experiments with the novel as a literary form. His works have also elicited commentary for their use of violence and terror, along with subconscious or dream-like imagery of a menacing and repulsive sort, which he treats in a coldly detached yet frequently comic manner. ${ }^{10}$ So it might seem at first that a

10 On Hawkes's blending of the repulsive or frightening with comedy, see, for example, Donald J. Greiner, Comic Terror: The Novel's of John Hawkes. Memphis, Tennessee, Memphis State University Press, 1973. 
Hawkes novel would hardly fit into the category of fiction being discussed here. But the motif of the protagonist's flight from a life-threatening or stultifying society to a natural landscape or haven which promises freedom and a new start retains enough suggestive power to influence even such a formal innovator as Hawkes. In Second Skin the protagonist, Skipper, a fat, bald ex-seaman now living on a warm Caribbean island, is writing an account of his life in which for the most part he switches back and forth between scenes from the idyllic island in the present and scenes from the past depicting his life on a cold island in the North Atlantic off the coast of the U.S. Everything about the cold island is connected with violence, darkness, and death. The chief figure dwelling on the island is a cruel widow named Miranda, Skipper's antagonist. Miranda incarnates the deathurges of the civilization Skipper eventually chooses to leave behind, a civilization which has been scarred by world war.

Virtually every important character in the novel has been affected, directly or indirectly, by the violence set loose in World War II. Moreover, the majority of them have internalized the violence and become psychologically deformed. They are attracted toward and serve the forces of death. It is this fate that Skipper hopes to escape. During the war Skipper, always inept and a bit comic, fails to stop the mutiny that is developing on his ship and is gang-raped by the leaders of the mutiny. His daughter's husband, a man named Fernandez whose homosexual nature emerges after their marriage, is sadistically maimed and murdered by sailors on leave who hate sexual inverts. Skipper's wife, lonely and sexually unsatisfied, has numerous affairs with sailors and eventually kills herself. After Skipper moves to the island in the North Atlantic, his widowed daughter Cassandra also kills herself, leaving behind an infant child named Pixie. (Skipper's father, an undertaker, was also a suicide many years earlier: violent death has always surrounded Skipper.) On the cold island they find a vicious young man, Jomo, who has lost a hand fighting at Salerno, and Miranda, the reigning goddess of death on this dank and evil place, has lost her husband Don to the Nazis.

Almost the first thing we learn about Miranda is that she enjoys listening to the "Horst Wessel Lied", a patriotic marching song favored by soldiers of the Third Reich. She presumably misses her husband, who sent her the recording of the song, yet she has somehow absorbed the spirit of violence linked with the Nazis who killed him. In one key scene, she listens to the song while reminiscing about Don, 
all the while confusing affection and love for him with the "Reichstag hysteria", 11 as Skipper calls it, expressed by the music. Her psychological nature has been foully warped by this confusion, as we see by what she has done a few minutes earlier: she has cut the tips of the nipples off Pixie's baby bottles with a pair of shears. The barbarous nature of this gesture strikes us with increased force when Miranda invites Skipper to sit down with her in front of the record player and have a drink, without acknowledging that anything is out of the ordinary. Later in the novel she encourages Skipper and Cassandra to take the boat trip with Jomo, his brother Bub, and their father Red on which Skipper is knocked unconscious with a tire iron by Bub, leaving Cassandra little choice but to surrender herself to the appetites of the men.

Almost any scene on the cold island could be offered to demonstrate Miranda's maliciousness or to point out the sadistic treatment of Skipper and Cassandra. Hawkes shows with ruthless clarity that the inhabitants of the island, which is but an extension of postwar America, have given themselves over to the practices of cruelty and the inflicting of pain. The evil of the place comes across all the more effectively because Skipper recounts the violence and suffering in the novel with almost no editorial commentary, in a manner that often seems absurdly naive and out of place. In the nipple-cutting scene, for example, he vividly describes what he sees, but hardly seems to register any reaction to it. He does not condemn Miranda's hideous conduct or express anger over it. Quite the contrary: he amiably joins her as she tells of Don, and he taps his shoe to the beat of the march, clearly aware of "the horror of the nipples" (p. 61) yet too genial to take action. But this is all a part of Hawkes's design: just as Twain uses an innocent boy in Huckleberry Finn to give a completely unbiased account of the degenerate people he encounters on his journey down the Mississippi, Hawkes chooses for a narrator a good-natured middle-aged man who is too easy-going and bumbling to protect himself and his daughter from the likes of Miranda or to react with the outrage and condemnation that we would normally expect. What results from Skipper's comic helplessness and apparent naiveté is that what he witnesses stands out in greater relief. His maddening passivity and

11 John HawkEs, Second Skin. New York, New Directions, 1964. All quotations are from this edition. Subsequent references will be found in the text in parentheses. 
misplaced gentleness tend to amplify the reader's sense of disgust and shock at the events Skipper writes about. His vulnerable, comic self offers maximum contrast to the perilous North Atlantic island, highlighting its life-denying essence, identifying it as what we might call the Kingdom of Thanatos.

Opposed to this realm is the warm island, the Kingdom of Eros, where even nature itself seems to be suffused with love and sexuality. Skipper, his old mess boy Sonny, and a fifteen —or sixteen-year-old island girl named Catalina Kate form the nucleus of this joyous little society. Skipper has left the orphaned Pixie with a relative and has retreated to a place where, to use his word, he might "redeem" all the deaths he has seen. He goes about redeeming his painful past in ways that both initiate and celebrate life. First of all, he and Sonny, a black man, have both enjoyed the love of Kate, whose pregnancy advances as Skipper narrates the novel. Either man might be the father of the child, but in this harmonious world it hardly seems to matter. The important point is that in place of the wife and daughter he has lost, Skipper now has Kate and eagerly looks forward to the delivery of her baby. Second, Skipper has taken up a new vocation on the island -artificially inseminating cows, a task that he and the others, including a tiny black nun named Josie, happily perform as a communal ritual. And, finally, Skipper redeems his past in the act of writing about it: the act of writing, of shaping language into an enduring artifact (the novel itself, which re-creates his experiences for us), represents a triumph through art over the death and chaos of his earlier life. In other words, the novel on its deepest level is about the power of the imagination - the magic of art- to transform painful realities into visions or images of order, peace, and beauty. The "second skin" of the title principally refers, then, to the artifice which is the novel itself, the "covering" or form which artfully worked language imparts to the raw experience of life.

Skipper, who remains an unheroic figure throughout the novel, nevertheless finally emerges as the artist-magician who imagines an island paradise to suit himself. And though his novel deals with the evils of human cruelty, suffering, and death, it has a happy, upbeat ending - which is to say that in its larger intentions it is a comedy rather than a tragedy. Kate's baby is born in the closing pages, as the narrative comes to its appropriate end, and the citizens of the warm island all celebrate the event by picnicking in a cemetery on the Night of All Saints. Skipper tells Kate than soon they will start 
another baby. Thus his story, his verbal art, serves life, not death. Eros has the last word over Thanatos.

Second Skin is the only recent American novel to present a fully imagined version of the happiness that awaits the male protagonist who withdraws from a sterile or life-denying society. Most of the other novels that use this motif end just as the central figure is leaving his familiar world, poised on the brink of a new life perhaps, but disillusioned and in flight. Yossarian, for example, thinks of the delights he will taste with the lovely women he assumes await him in Sweden, but when we see him for the last time, he is still trying to escape from the whore with the knife. Another unique feature of Second Skin lies in Hawkes's conception of the protagonist's new beginning as a paradise that involves a woman, a baby, and the responsibilities of caring for a family. Even though Skipper has run from a veritable witch and has suffered his wife's infidelities, he does not seek to escape from contact with the female sex. It is true that Catalina Kate is as much a girl as she is a woman and that she is younger than Skipper's daughter, but she has not been exploited by him. Her relationship with Skipper and Sonny is perfectly in tune with the healthy rhythms of life on the Caribbean island.

Hawkes's plan, of course, calls for the elimination of any practical difficulties that might arise from such a relationship because he wants to underscore the point that Skipper's paradise exists in the fabric of words that Skipper has woven for the reader -in other words, in the world of the imagination. Hawkes implants several allusions in Second Skin to Shakespeare's The Tempest. Miranda's name, for example, comes from the play. Skipper refers to himself as "old Ariel in sneakers" (p. 162). And the magic island itself, where chaos and cruelty are transformed into harmony and love, reflects Prospero's enchanted island and Prospero's powers as a magician. In addition, Hawkes makes the novel highly self-reflexive. Skipper frequently draws our attention to his actual writing of the novel and to the novel itself as a verbal artifice. Not only the allusions to The Tempest but also the reminders that Second Skin is a work of literary art and not a map of the real world reinforce the same point - that Skipper's magic island, like Prospero's, exists in an imaginative realm.

Perhaps Hawkes has found the only solution to the fundamental problem facing the protagonist whose story traces his unhappy engagement with society and his withdrawal from it. The problem is this: where to go? All societies are to one degree or another corrupt, 
and all social arrangements require that some measure of individual freedom be given up. To be sure, the motifof the protagonist's escape from a society that endangers his freedom and sense of self outlines an American myth; it does not propose a practical line of action. Still, we are entitled to ponder the implications of a story so long imbedded in the American consciousness. If society is stained with evil to the extent that the comparatively innocent protagonist recoils from it and must leave it, where will he end up, and what will his life be like? Updike's novel shows that Rabbit has no place to go: Rabbit just runs. (In Rabbit Redux and Rabbit is Rich, which follow this character's life in later years, he returns to the same setting of the first novel and resumes his old life as well as he can.) In Catch-22 Yossarian heads for a Sweden/Eden that may or may not live up to his expectations (if he can even reach the place). But the whole point of the plot is to set him in motion, to make him start running, just as Chief Broom and Stephen Rojack have to get away from the surrounding sickness and danger first and consider their options later. Hawkes, however, concocts a different fate for Skipper, one that paradoxically sidesteps and confronts the issue of where to go and what to do. In timehonored fashion, Skipper skips out; but then he goes on to achieve what all the others have always wanted - paradise, no less, with constant sunshine and uncomplicated love.

This is the only proper home for the literary protagonist whose noble ancestor is the American Adam. The descendants of this figure seek to return to their rightful birthplace, which in our literary and cultural tradition is normally associated with the frontier or some other beckoning landscape beyond the borders of civilization. They want to reach a safe, natural locale far from decadent cities and social entanglements that tame the free spirit of a man. Hawkes sets Skipper down in such a place and then makes us realize that it exists only on the printed page, in the world of words, the realm of art, where every known paradise has so far been found. 